\title{
FORMS OF INDECENT DRESSING AMONG UNIVERSITY STUDENTS IN NORTH CENTRAL GEO-POLITICAL ZONE
}

\author{
OSAGIOBARE, EMMANUEL OSAMIRO; EKWUKOMA, VICTOR, AND \\ EKOMARU, CHINYERE IHUOMA,
}

\begin{abstract}
The study investigated the malaise of indecent dressing that has pervaded the Nigerian university campuses. One research question and a hypothesis were raised to give direction to the study. The instrument used was a questionnaire entitled "Indecent Dressing in the University Questionnaire (IDUQ)". IDUQ was administered to 300 students randomly selected from six universities in the North Central Geopolitical Zone of Nigeria. The data collected were analysed with frequency counts, percentages and One-Way Analysis of Variance (ANOVA). The results of the analysis showed that a high percentage of the respondents agreed that most of the forms of indecent dressing listed in the questionnaire were common among university students. The result further revealed that there was a significant difference in the modes of dressing of students in private, state and federal government owned universities, in various forms. The pair wise comparison showed that the difference exists between federal and private universities; state and private universities whereas there was no difference between federal and state universities. Based on the findings, it was recommended, among other things, that university authorities should take decisive steps in curbing this social malaise (indecent dressing) by introducing dress codes for students and strictly enforcing it.
\end{abstract}

\section{Introduction}

The menace of indecent dressing in most Nigerian universities has reached an alarming proportion. It has become so pervasive that those who dress decently are seen as abnormal or uncivilised members of the university community. Some university students, especially the female students are almost going nude all in the name of fashion. They have invented a strange sub-culture of nudity in public places through their desperate attempts to be fashionable. Most campuses are drowning in morally offensive and sexually provocative dressing. One can hardly differentiate between some male and female university students and hard-core urban street thugs and prostitutes respectively.

Some of these young people who dress indecently appear not to be aware of the saying that "one should dress the way one would want to be addressed". Efforts by some older members of society to correct this negative trend have not only become fruitless but have also presented them in a very bad light as primitive, uncivilised, naive and abnormal members of society. Some of such adults have learnt to cope with the worrisome development by adopting the approach of "looking - the - other - way" and turning a blind-eye to the misadventure of the youths most of whom are very ready to pounce on anyone who dares make an uncomplimentary remark on their dressing. Unfortunately, there are some parents who do not only dress indecently but also encourage their children in the university to dress indecently by either sending money to them to buy such dresses or going to the market to buy it for them.

Indecent dressing is any form of dressing that is likely to shock/offend others, or elicit sexual provocation. It is any form of dressing that does not properly cover the sexually sensitive parts of the body such as the armpit, cleavage, breast, thighs, buttocks, navel, the chest of a male, the back of a female, and so on. Omede (2011) remarked that a dress is 
said to be indecent when it has a provocative or stimulating influence on almost all those that happen to view it on the user. Ako \& Igbo (2013) sadly noted that most tertiary institutions are replete with dresses that can be described as indecent. For instance, some females put on trousers that expose their underwear when they bend down or take a sitting position. This exposure, according to Omede (2011) cited in Ako \& Igbo (2013), is a deliberate act to look sensuous, tantalizing and stimulating so as to attract the attention of the opposite sex. This act is more prevalent among the singles (unmarried women and men).

Arguably, the menace of indecent dressing in some universities is a spill over from the larger society that is flooded with indecent dressing especially among the singles. However, some married people especially women also dress indecently. There are those of them who claim that indecent dressing is a strategy for "protecting" their homes. They presumably feel that when they dress indecently (revealing the parts of their body that are supposed to be concealed) their unfaithful husbands would not have any cause of looking at husband snatchers who dress indecently as a bait. However, whether their strategies are justifiably yielding good results or not is beyond the purview of this study.

Akor (2006) posited that some male students put on trousers and tops with strange designs and pictures of scary animals like dragons. Ako and Igbo (2013) also added that some male students dress indecently by making their boxers show above their trousers. There are those who tie headgears like ladies, have their ears and other parts of their bodies like the mouth and the nose pierced in order to wear rings on them. Some, in their care for cheap attention, maintain spiky and unkempt hairstyles resembling everything from the horse's mane. Wearing of earrings by the male folks and the inscription of tattoos on the human skin by both male and female folks are fast becoming hallmarks of "civilisation" to some university students who idolize whatever is latest such as celebrities, clothes, accessories, hairdo, tattoo and music, be it rock, rap, jazz or just noise. To them, it does not matter what the lyrics of the song is - senseless, gothic, or immoral - as long as their peers approve of it. A careful observation of students from any vantage point in most universities would reveal how so many female folks in the university wear tight-fitting, virtually painted-on outfits that are provocatively flashy and attention-getting, revealing parts of the body that are meant to be concealed. They relish in exposing to the public gaze their bare breasts, arms, and lower limbs. Unfortunately, some campus fellowships and religious worship centres (just like in the larger society) have become theatres of lewdness and indecent dressing.

Expectedly but disheartening, the indecent dresses are imported and/or invented alongside their names. Some of them according to Aiyeyika (2010) include:

- $\quad$ Off Shoulder: Tops that expose the shoulders and some parts of the breasts.

- Tube: Tops that cover only the breast region, exposing the stomach and shoulder region.

- $\quad$ See My Navel/Belly: Tops that expose mainly navel region and upper pubic hair.

- Show Back: Tops with no hand but have tiny ropes that are tied round the neck and are open at the back.

- $\quad$ My Bra is Cute: Tops with very tiny hands that expose the brassieres.

- Look But Don't Touch: Tops that reveal at least three quarters of the breast, usually worn with the type of brassiere that pushes up the breast almost to the neck level. 
- See Me Through/ Show Glass: Transparent wears that expose the inner body showing the complexion and all the vital endowments of the individual.

- Hot Midi/ Skin Tight: A very tight long skirt that reveals the exact contours of the buttocks with slits on both sides.

- $\quad$ Micro/ Mini Skirt: Extremely short skirts that stop many inches above the knee.

- I Am Aware Jeans: Jean trousers that expose some parts of the buttocks and even the line of the buttocks.

- $\quad$ Millennium Trousers: Trousers made with light materials and worn to reveal all contours of the buttocks, including the line of the buttocks.

- $\quad$ Net Tops: Tops made with net which expose the inner wear like brassiere and the body.

- Indomie /Hand Spaghetti: Half tops that expose more than half of the breast region.

- $\quad$ Fitted: Clothes made to follow the shape of the body.

- Born Shorts: These are very tight and pants-like shorts (worn by some girls) that reveal the contours of the buttocks.

\section{Statement of the Problem}

The problem that necessitated this study is the prevalence of indecent dressing among university students in Nigeria. It is very worrisome that this menace of indecent dressing which is an act of moral indiscipline has pervaded the university which is the highest institution of learning all over the globe. The sociological problem of indecent dressing in the university system requires an urgent attention by concerned authorities because it is the mother of many other social vices such as sexual harassment, rape, etc. The exposure of the sensitive parts of a woman, for example, can arouse sexual urge in men and in extreme cases lead to rape. Rape can lead to unintended pregnancy and the latter can lead to abortion/STDs. School dropout or death (any of which results in the termination of educational aspiration) is usually the outcome of cases of abortion and STDs.

\section{Purpose of the Study}

The primary purpose of this study was to:

- Determine the forms of indecent dressing that are prevalent in the universities that are located in the North-Central Geo-political Zone of Nigeria.

- $\quad$ Determine whether the menace of indecent dressing is prevalent in all categories of universities (federal, state and private) located in the North Central Geopolitical Zone of Nigeria.

\section{Research Question}

What are the forms of indecent dressing that are prevalent in the universities that are located within the North Central Geo-political Zone?

\section{Hypothesis}

There is no significant difference in the involvement of students in private, state and federal government owned universities in acts of indecent dressing. 


\section{Significance of the Study}

The study will help to bring to the fore the negative educational and sociological implications of indecent dressing in the university system. Furthermore, the study will suggest effective strategies for curbing the menace of indecent dressing in our universities. Lastly, students, scholars and researchers who may be interested in related studies will find the study handy for literature review.

\section{Methodology}

The researchers adopted an ex-post facto design. The population of the study consisted of all the university students in the North-Central Zone. The North-Central States are Benue, Kogi, Kwara, Nasarawa, Niger, Plateau and the Federal Capital Territory - Abuja. Three hundred (300) students were randomly selected for the study. A stratified random sampling procedure was used to select three universities (one private, one state and one federal university). One hundred students were drawn from each of the three universities. A questionnaire entitled "Indecent Dressing in the University Questionnaire (IDUQ)" was used to collect data. The IDUQ has a test-retest reliability coefficient of 0.66 . It had two sections - A and B. Section A elicited the background information of the respondents while section B provided statements which were used to elicit information about indecent dressing.

\section{Results}

Research Question: What are the forms of indecent dressing that are prevalent in the universities that are located within the North Central Geo-political Zone?

Table 1: $\quad$ Forms of Indecent Dressing Among University Students in the North Central Geo-political Zone

\begin{tabular}{llll}
\hline S/No. & Forms of Indecent Dressing & \multicolumn{1}{c}{$\begin{array}{c}\text { Agreed } \\
\mathrm{F}(\%)\end{array}$} & $\begin{array}{c}\text { Disagreed } \\
\mathrm{F}(\%)\end{array}$ \\
\hline 1. & Tying of headgears by male students & $50(16.7)$ & $250(83.3)$ \\
2. & Keeping of spiky and unkempt hairstyle by male & $230(76.7)$ & $70(23.3)$ \\
& students & & \\
3. & Off shoulder & $270(90)$ & $30(10)$ \\
4. & Tube & $220(73.3)$ & $80(26.7)$ \\
5. & See my navel & $132(44)$ & $168(56)$ \\
6. & Show back & $265(88.3)$ & $35(11.7)$ \\
7. & My bra is cute & $239(79.7)$ & $61(20.3)$ \\
8. & Look but don't touch & $200(66.7)$ & $100(33.3)$ \\
9. & See me through & $130(43.3)$ & $170(56.7)$ \\
10. & Hot midi & $100(33.3)$ & $200(66.7)$ \\
11. & Mini skirt & $285(95)$ & $15(5)$ \\
12. & Millennium trousers & $170(56.7)$ & $130(43.3)$ \\
13. & Net tops & $180(160)$ & $120(40)$ \\
14. & Spaghetti & $205(68.3)$ & $95(31.7)$ \\
15. & Sagging trousers & $275(91.7)$ & $25(8.3)$ \\
16. & Abnormally dark and very big sunglasses & $291(97)$ & $09(3)$ \\
17. & Bon shorts & $289(96.3)$ & $11(3.7)$ \\
\hline
\end{tabular}


Table 1 above shows that a very high percentage of the respondents agreed that all the items above - except tying of headgears by male students $(16.7 \%)$, see me through $(43.3 \%)$ and hot midi $(33.3 \%)$ - are forms of indecent dressing in the university. Below is a graphical representation of the percentage of agreed responses:

Figure1: Graphical Representation of Percentage (\%) of Agreed Responses

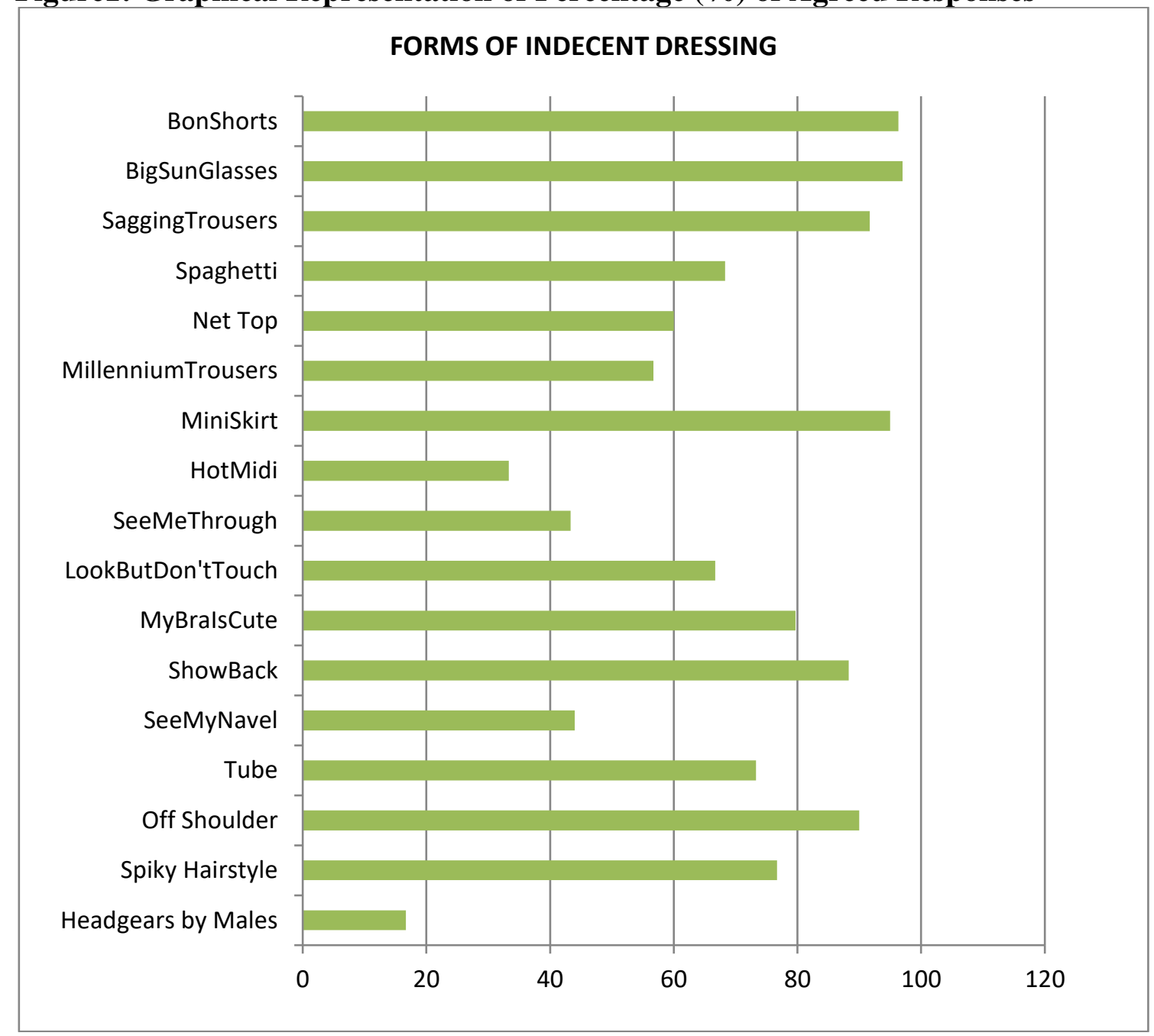

Hypothesis: There is no significant difference in the involvement of students in private, state and federal government owned universities in acts of indecent dressing.

Table 2: $\quad$ ANOVA Result on Indecent Dressing in Three Types of Universities in North Central Geo-Political Zone

\begin{tabular}{lllllll}
\hline Source of Variations & SS & DF & MS & F-ratio & Sig. & Decision \\
\hline Between Group & 0.507 & 2 & 0.253 & & & \\
Within Group & 266.490 & 297 & 0.897 & & & \\
\cline { 1 - 5 } Total & 266.997 & 299 & & 0.282 & 0.014 & Significant \\
\hline
\end{tabular}

An examination of table 2 above shows $\mathrm{p}<0.05$. Consequently, the null hypothesis that there is no significant difference in the involvement of students in private, state and federal government owned universities in acts of indecent dressing is rejected while the alternate hypothesis is accepted. This means that there is a significant difference in the 
involvement of students in private, state and federal government owned universities in acts of indecent dressing.

Since the result is significant, it became imperative to find out where the differences lie among the group means. Turkey was used for pair wise comparisons. The results of the comparisons are presented in table 3 below.

Table 3: $\quad$ Multiple Comparisons

\begin{tabular}{|c|c|c|c|c|c|c|}
\hline \multirow{2}{*}{$\begin{array}{l}\text { (I) } \\
\text { VAR0 } \\
0001\end{array}$} & \multirow{2}{*}{$\begin{array}{l}(\mathrm{J}) \\
\text { VAR0 } \\
0001 \\
\end{array}$} & \multirow{2}{*}{$\begin{array}{l}\text { Mean } \\
\text { Difference (I- } \\
\text { J) }\end{array}$} & \multirow{2}{*}{ Std. Error } & \multirow[b]{2}{*}{ Sig. } & \multicolumn{2}{|c|}{ 95\% Confidence Interval } \\
\hline & & & & & $\begin{array}{l}\text { Lower } \\
\text { Bound }\end{array}$ & Upper Bound \\
\hline \multirow[t]{2}{*}{1} & 2 & -.06000 & .13396 & .895 & -.3755 & .2555 \\
\hline & 3 & $-.10000 *$ & .13396 & $-.736 *$ & -.4155 & .2155 \\
\hline \multirow[t]{2}{*}{2} & 1 & .06000 & .13396 & .895 & -.2555 & .3755 \\
\hline & 3 & $-.04000 *$ & .13396 & $-.952 *$ & -.3555 & .2755 \\
\hline \multirow[t]{2}{*}{3} & 1 & $.10000^{*}$ & .13396 & $-.736^{*}$ & -.2155 & .4155 \\
\hline & 2 & $.04000 *$ & .13396 & $-.952 *$ & -.2755 & .3555 \\
\hline
\end{tabular}

From table 3 above, all the group comparisons showed that there is no significant difference between federal universities and state universities (Sig $=0.895, \mathrm{p}>0.05)$, but there is a significant difference between federal and private universities ( $\mathrm{Sig}=-0.736$, $\mathrm{p}<0.05$ ) and there is a significant difference between state and private universities ( $\mathrm{Sig}=-$ $0.952, \mathrm{P}<0.05)$.

\section{Discussion}

The answer to the research question (shown in table 1) reveals that a very high percentage of the respondents agreed that all the items above - except tying of headgears by male students $(16.7 \%)$, see me through $(43.3 \%)$ and hot midi $(33.3 \%)$ - are forms of indecent dressing in the university. This finding is in agreement with several authors who had identified most of the items in table 1 as forms of indecent dressing in higher institutions (Aliyu, 2008; Aiyeyika, 2010; Boyi, 2013 and Kanu \& Akanwa, 2012).

The finding of the hypothesis is that there is a significant difference in the involvement of students in private, state and federal government owned universities in acts of indecent dressing. The post hoc comparison shows that there are significant differences between federal and private universities, state and private universities. However, there is no significant difference between federal and state universities. This result can be explained from the perspective of the fact that some private universities that are faith-based have dress codes for their students - unlike most federal and state universities that have no dress codes. In other words, the incidence of indecent dressing is higher in state and federal universities than private universities.

Arguably, indecent forms of dressing (as identified in this study) could have sociological and educational implications. Indecent dressing is the root of so many vices because the exposure of the sensitive parts of a woman, according to Akor (2006) cited in Ako and Igbo (2013), can arouse sexual urge in men and in extreme cases lead to rape. Ekwukoma (2014) posited that rape, which is the crime of some male students forcing female 
students to have sex with them, has become a very worrisome social problem spreading like wildfire, perhaps unnoticeably, in most public universities. It probably has not dominated discussions of major stakeholders because a very large number of rape cases are not reported by the victims. There are dissenting opinions with regard to the factors contributing to its increasing rate. However, a preponderance of opinions attributes it to some females' sub-culture of going nude in the name of fashion. The grave consequences of rape include unintended pregnancies, sexually transmitted diseases (such as HIV/AIDS, gonorrhoea, human papilomavirus, genital herpes, hepatitis B and so on), emotional stress, risk of abortion, shame or guilt and so on which can have a negative implication on the educational aspiration of the victims. So, indecent dressing can lead to rape; rape can lead to unintended pregnancy; unintended pregnancy can lead to abortion or school dropout and abortion can lead to death (the end of life and educational aspiration of the individual). The interconnectedness can be illustrated with the model below:

Indecent dressing $\rightarrow$ Rape $\rightarrow$ Unintended pregnancy $\rightarrow$ Abortion/STDs $\rightarrow$

School dropout/death (Termination of educational aspiration).

Source: $\quad$ Authors' design (2014).

\section{Conclusion}

The menace of indecent dressing that has become a characteristic feature of most streets in Nigeria has unfortunately overwhelmed most Nigerian university campuses. This scourge of indecent dressing has grave sociological and educational implications. The growing incidence of rape cases in the society can be traced to the prevalence of indecent dressing. Besides rape, indecent dressing is an act of indiscipline which could impede learning. An individual who lacks discipline can hardly learn because discipline and learning are the two sides of a coin.

\section{Recommendations}

Based on the findings of this study, the following recommendations were made:

i. University authorities should take decisive steps in curbing this social malaise (indecent dressing) by introducing dress codes for students and strictly enforcing it.

ii. Seminars and workshops should be organized periodically by the university counselling units to enlighten students on the danger of indecent dressing and other social vices.

iii. Parents should teach their children how to dress decently from their tender age long before they enter the university. They should show them good examples.

iv. Religious organisations should preach and emphasise decent dressing. It should not be compromised because of the unnecessary quest for numerical growth. 


\section{References}

Aiyeyinka, R.F. (2010). Consequences of indecent dressing among university students: Implications for counselling. The Counselor: A Journal of Counselling Association of Nigeria, 26: 61-69.

Ako, J. A. \& Igbo H.I. (2013). Moral discipline issues among tertiary institution students in Nigeria. The Nigerian Educational Psychologist, 11(1): 198-205.

Akor, R.A. (2006). Indecent dressing on campuses: The way out. In Ortese, P.T. (Ed.). Towards functional and qualitative education in Nigeria. Makurdi: Destiny Ventures.

Boyi, A. (2013). Causes and implications of indiscipline among students of tertiary institutions in Nigeria. The Nigerian Educational Psychologist, 11(1): 20-29.

Ekwukoma, V. (2014). Corruption in the university system: A challenge to quality assurance. An unpublished $\mathrm{PhD}$ thesis proposal, Faculty of Education, University of Benin.

Kanu, S. I. \& Akanwa, U.N. (2012). Unethical practices in the Nigerian educational system. Interdisciplinary Journal of Contemporary Research in Business, 4(8). Retrieved from ijcrb.webs.com on the 19/05/2014.

Omede, J. (2011). Indecent dressing on campuses of higher institutions in Nigeria: Implications for counselling. Journal of Emerging Trends in Education Research and Policy Studies (JETERAPS), 2(4): 228-233. 